\title{
Constraints to the Application of Online Learning during the Covid-19 Pandemic
}

\author{
Tedi Rusman ${ }^{1}$, Maskun $^{2}$, Suroto $^{3}$ \\ \{rusmantedi@ymail.com¹ ${ }^{1}$, maskun.1959@fkip.unila.ac.id ${ }^{2}$, suroto.1993@ fkip.unila.ac.id ${ }^{3}$ \}
}

Economic Education, University of Lampung, Bandar Lampung, Indonesia ${ }^{1,3}$, Historical Education, University of Lampung, Bandar Lampung, Indonesia ${ }^{2}$

\begin{abstract}
The Covid-19 pandemic is rapidly changing many aspects of life. The learning process is also forced to adjust quickly. This study aims to reveal the effectiveness of online learning and in detail reveal the obstacles to implementing online learning during the Covid-19 pandemic based on several recent studies. This study applies the literature review method and journals related to the constraints and effectiveness of online learning, especially during the Covid-19 pandemic. The data collection technique was done by using observation, questionnaire, interview and documentation. The population in this study were all undergraduate students of Semester VI with a sample of 32 students who were taken by simple random sampling technique. The results of this study reveal that online learning during the Covid-19 pandemic has been ineffective and there are still many obstacles to be faced. In order for learning to be effective and smooth, special guidance is needed for both teachers and students.
\end{abstract}

Keywords: Learning Constraints, The Covid 19 Pandemic, Online Learning.

\section{Introduction}

Education is a conscious and planned process carried out to those who are given responsibility, namely educators to educate students so that they have character and behavior by the ideals of the goals of national education. "Education is expected to be properly directed to make students able to achieve the process of maturity and independence in social life" [1]. Therefore, education should be carried out utilizing continuous and intensive.

The educational efforts above have not been fully implemented properly, the real obstacle now is the outbreak of a pandemic caused by the Corona virus (Covid 19) in almost all parts of the world, the impact of this pandemic is devastating in all aspects of life. As the impact of one of them in the field of education, especially in changing all processes in classroom learning. There are many ways that the government has done to prevent its spread. One of them is through a circular letter from the Ministry of Education and Culture (Kemendikbud) of the Directorate of Higher Education Number 1 of 2020 concerning the prevention of the spread of Corona Virus Disease (Covid-19) in universities. Through this circular, "The Ministry of Education and Culture gives instructions to educational institutions and universities to organize distance learning (online) and advises students to study from their homes" [2].

As stated in the Ministry of Education and Culture's circular information above, several universities responded swiftly to these instructions, one of which was the University of Indonesia which issued a circular on alertness and prevention of the spread of Covid-19 infection within the University of Indonesia. According to Yandwiputra, that the letter contains 10 points, one of which is an appeal to change face-to-face learning into distance learning) [3]. 
As reported by Indonesia, that there are at least 65 universities in Indonesia that organize lessons from home to prevent the spread of Covid-19) [4].

In an effort to prevent the spread of Covid-19, the world health agency (WHO) "... recommends temporarily stopping activities that could potentially cause crowds. For this reason, conventional learning that gathers many students in one room needs to be reviewed for its implementation" [5]. "Learning must be carried out with a scenario that can minimize physical contact between students and other students, or between students and lecturers. In line with these conditions" [6], according to Milman, "...the use of digital technology allows students and lecturers to be in different places during the learning process" [7].

One of the alternative forms of "...learning that can be carried out during the Covid-19 pandemic emergency is online learning" [8]. According to Moore et al. [9], online learning refers to "...learning conducted using an Internet network with connectivity, accessibility, flexibility, and the ability to generate various types of learning interactions" [10]. Research efforts stated by Zhang et al. show that "The use of the internet and multimedia technology is able to change the way of conveying knowledge and can be an alternative to learning carried out in traditional classrooms" [11].

The process of distance learning (online) in its implementation requires the support of electronic devices such as smart phones, computers, android tablets and laptops that can support and access information. According to Korucu \& Alkan, that "The use of mobile technology has a major contribution in the world of education, including the achievement of distance learning goals" [12]. implementation of online learning can be supported by various media [13]. For example, virtual classes use Edmodo, and Google Classroom services [14],[15], and instant messaging applications such as WhatsApp [16]. "Online learning can even be done through social media such as Facebook and Instagram" [17].

However, this is because "The use of information and communication technology with online learning that is not prepared from the start has resulted in a lot of obstacles faced by both educators and students [18]. This study aims to determine what factors are the obstacles in the application of online learning during the Covid-19 pandemic at the FKIP, University of Lampung. Combined with the discovery of obstacles encountered in online learning, this research is expected to be used as a consideration for lecturers and students in the process of teaching and learning activities. Therefore, teaching and learning activities can be performed optimally.

\section{Method}

This research is a descriptive verification research with ex post facto research methods and surveys. This research was conducted to determine the obstacles to online learning during the Covid-19 pandemic. The population used was the 6th semester students of FKIP University of Lampung. The sample was taken in this study using simple random sampling technique with a total sample of 32 students.

The data collection techniques used by researchers are observation, recording, interview and questionnaire survey techniques. 1) Observation, this technique is carried out to observe the conditions in the field when conducting preliminary research, namely to observe the learning process, see the facilities and observe the lecture environment. 2) Documentation is used to collect data that is already available in document records. In social research, the function of data derived from documentation is mostly used as supporting and complementary data for primary data obtained through observation and interviews 3) Interviews are used to obtain data in the 
form of data in preliminary studies to find problems that must be researched, to determine student needs and to find out the problem in depth, and 4) The questionnaire in this study was conducted by giving questions or written statements to the research sample to obtain information about student needs for the learning characteristics needed in learning.

\section{Results and Discussion}

This research was conducted to obtain data as the research objectives, namely 1). Knowing the obstacles to implementing online learning during the Covid-19 pandemic, and 2) Knowing the effectiveness of online learning during the Covid-19 pandemic. In line with these objectives, the researchers distributed questionnaires. Based on the results of distributing questionnaires to 32 respondents, the percentage of data for each question item was obtained as follows.

Table 1. Results of the Distribution of Input Variable Questionnaires in Online Learning.

\begin{tabular}{|c|c|c|c|c|c|c|}
\hline \multirow{2}{*}{\multicolumn{2}{|c|}{ Variable }} & \multirow{3}{*}{$\begin{array}{l}\text { Statement } \\
\text { The material is in accordance with } \\
\text { the learning objectives }\end{array}$} & \multicolumn{4}{|c|}{ Percentage of Respondents } \\
\hline & & & \multirow{2}{*}{$\begin{array}{c}\begin{array}{c}\text { Totally } \\
\text { disagree }\end{array} \\
-\end{array}$} & \multirow{2}{*}{$\begin{array}{c}\text { Disagree } \\
-\end{array}$} & \multirow{2}{*}{$\begin{array}{c}\text { Agree } \\
46.9 \%\end{array}$} & \multirow{2}{*}{$\begin{array}{c}\begin{array}{c}\text { Strongly } \\
\text { Agree }\end{array} \\
46.9 \%\end{array}$} \\
\hline & & & & & & \\
\hline & $\begin{array}{l}\text { Lecture } \\
\text { Materials }\end{array}$ & $\begin{array}{l}\text { The material is equipped with } \\
\text { media and supporting materials }\end{array}$ & - & $12.5 \%$ & $59.4 \%$ & $28.1 \%$ \\
\hline & & $\begin{array}{l}\text { The material is in accordance with } \\
\text { the development }\end{array}$ & & $12.5 \%$ & $56.3 \%$ & $31.3 \%$ \\
\hline \multirow[t]{4}{*}{$\begin{array}{l}\text { Learning } \\
\text { Input }\end{array}$} & $\begin{array}{l}\text { Lecture } \\
\text { Facilities }\end{array}$ & $\begin{array}{l}\text { Learning tools and media are } \\
\text { available in full }\end{array}$ & $6.3 \%$ & $25 \%$ & $43.3 \%$ & $25 \%$ \\
\hline & & Class management & - & $21.9 \%$ & $62.5 \%$ & $15.6 \%$ \\
\hline & Lecturer & $\begin{array}{l}\text { Lecturers have qualifications in the } \\
\text { material being taught }\end{array}$ & $3.1 \%$ & $3.1 \%$ & $34.4 \%$ & $59.4 \%$ \\
\hline & Curriculum & Complete lecture tools & & $18.8 \%$ & $62.5 \%$ & $18.8 \%$ \\
\hline
\end{tabular}

Based on the data from the table above, it can be seen that the percentage distribution of learning input for aspects of learning material is in a good category, which makes the obstacles in learning input are media, teaching materials, aids, lecturer qualifications, and learning devices.

Table 2. Results of the Distribution of Process variable Questionnaires in Online Learning.

\begin{tabular}{ccc}
\hline Variable & Statement & Percentage of Respondents \\
\hline
\end{tabular}




\begin{tabular}{|c|c|c|c|c|c|c|}
\hline & & & $\begin{array}{c}\text { Totally } \\
\text { disagree }\end{array}$ & Disagree & Agree & $\begin{array}{c}\text { Strongly } \\
\text { Agree }\end{array}$ \\
\hline \multirow{7}{*}{ Process } & \multirow{2}{*}{$\begin{array}{l}\text { Lecture } \\
\text { Strategy }\end{array}$} & $\begin{array}{l}\text { The learning process is in } \\
\text { accordance with student } \\
\text { development }\end{array}$ & - & $25 \%$ & $71.9 \%$ & $12.5 \%$ \\
\hline & & $\begin{array}{l}\text { The lecture process is in } \\
\text { accordance with the model / } \\
\text { method presented }\end{array}$ & - & $25 \%$ & $53.1 \%$ & $21.9 \%$ \\
\hline & \multirow{2}{*}{$\begin{array}{l}\text { Learning } \\
\text { Media }\end{array}$} & $\begin{array}{l}\text { The media provided is in } \\
\text { accordance with the learning } \\
\text { objectives }\end{array}$ & - & $15.6 \%$ & $75 \%$ & $9.4 \%$ \\
\hline & & $\begin{array}{l}\text { Learning media in accordance } \\
\text { with student development }\end{array}$ & - & $12.5 \%$ & $68.8 \%$ & $18.8 \%$ \\
\hline & \multirow{3}{*}{$\begin{array}{l}\text { How to teach } \\
\text { lecturers }\end{array}$} & $\begin{array}{l}\text { Lecturers can guide the class } \\
\text { well }\end{array}$ & - & $6.3 \%$ & $56.3 \%$ & $37.5 \%$ \\
\hline & & $\begin{array}{l}\text { Lecturers master the material } \\
\text { well }\end{array}$ & - & $3.1 \%$ & $50 \%$ & $46.5 \%$ \\
\hline & & $\begin{array}{l}\text { Lecturers always provide } \\
\text { motivation when learning } \\
\text { online }\end{array}$ & - & $12.5 \%$ & $62.5 \%$ & $25 \%$ \\
\hline
\end{tabular}

Based on the table data above, it can be seen that the percentage distribution of the learning process in its implementation is in the moderate category, which makes the obstacles in the learning process are methods, media suitability, guidance, mastery of material, and giving motivation.

Table 3. Results of the Distribution of Output variable Questionnaires in Online Learning.

\begin{tabular}{|c|c|c|c|c|c|c|}
\hline \multirow[b]{2}{*}{ Variable } & & \multirow[b]{2}{*}{ Statement } & \multicolumn{4}{|c|}{ Percentage of Respondents } \\
\hline & able & & $\begin{array}{c}\text { Totally } \\
\text { disagree }\end{array}$ & Disagree & Agree & $\begin{array}{c}\text { Strongly } \\
\text { Agree }\end{array}$ \\
\hline \multirow{5}{*}{$\begin{array}{l}\text { Learning } \\
\text { outcome } \\
\text { test output }\end{array}$} & \multirow{2}{*}{ Theory } & $\begin{array}{l}\text { Final exam questions or } \\
\text { assignments in } \\
\text { accordance with the } \\
\text { material being taught }\end{array}$ & & $6.3 \%$ & $53.1 \%$ & $40.6 \%$ \\
\hline & & $\begin{array}{l}\text { The online questions } \\
\text { provided can foster } \\
\text { students' thinking. }\end{array}$ & & $12.5 \%$ & $68.8 \%$ & $18.8 \%$ \\
\hline & \multirow[b]{2}{*}{ Construction } & $\begin{array}{l}\text { The question sentences } \\
\text { did not confuse students }\end{array}$ & & $21.5 \%$ & $56.3 \%$ & $21.9 \%$ \\
\hline & & $\begin{array}{l}\text { Pictures and graphics } \\
\text { provided can be read } \\
\text { clearly }\end{array}$ & & $15.6 \%$ & $53.1 \%$ & $31.1 \%$ \\
\hline & Language & $\begin{array}{l}\text { The language used in } \\
\text { online questions is in } \\
\text { accordance with the rules }\end{array}$ & & $3.1 \%$ & $71.9 \%$ & $25 \%$ \\
\hline
\end{tabular}


of Improved Spelling

(EYD).

The language used in

online questions can be

understood easily

Based on the data from the table above, it can be seen that the percentage distribution of learning output in its implementation is in a good category, which makes the obstacles in the output of learning outcomes are the suitability of the questions, the clarity of the questions, and the language used. These factors ultimately result in less optimal learning quality.

\section{Discussion}

In the current era of globalization and information, "The use of technology in learning has become a necessity and demand" [19]. however, its implementation is not an easy thing. When using media, we must pay attention to several techniques to make the best use of the media used and not deviate from the goal of learning media [20].

Learning can take place more dynamically than if it is only learning to use computers. "People can study anywhere, anytime and under any situation" [21]. Lectures can not only be done through face-to-face processes between lecturers and students. Now, students can still study even though they are far from the lecturer. In line with this, Trianto states that "Learning is a conscious effort from a teacher to teach students (directing student interaction with other learning sources) in order to achieve the goal" [22].

The constraints that have been described in the research results are learning inputs in the form of: media, teaching materials, aids, lecturer qualifications, and learning devices. In the learning process in the form of: methods, media suitability, guidance, mastery of the material, and giving motivation and the output of learning outcomes in the form of: suitability of questions, clarity of questions, and the language used. These factors ultimately result in less optimal learning quality. These various obstacles occur because of forced transitions or changes in lectures, educators should not be ready to prepare to change teaching online based on technology compared to conventional lectures. As stated by Sadiman, that in terms of procurement readiness, media are grouped into two types, namely ready-to-use media because it is a trading commodity on the broad market in a ready-to-use state (media by utilization) and a design media that needs to be designed and specially prepared for specific learning purposes and objectives [23].

These constraints are also caused by differences in age and proficiency in using technology between students and lecturers. Students today can be said to be digital natives. According to Virginia, the generation called digital natives is a generation that grows when technology develops [24]. In contrast to digital immigrants, digital natives are very fluent in the use of new media [24], this is because new media give rise to technological divide. This condition is a kind of gap between those who are sophisticated in terms of technology and those who are not sophisticated in terms of technology [25].

Another fact about the habit of digital natives is their interaction patterns. Palfrey \& Gasser state that the habit of digital natives includes: 1) This generation is different. They learn, work, write and interact with others in a different way. 2) Prefer reading blogs than newspapers. 3) Prefer to meet other people online. 4) Go to the library less often. 5) They prefer to send instant 
messages (IM) rather than pick up the phone. 6) They adopt and play with pets online instead of playing with real pets. And 7) The majority of aspects of their life are mediated by digital technology [26]. So it can be seen that in the online learning process, educators can always adjust to their skills or skills in using technology.

\section{Conclusion}

The use of technology in learning is an irresistible necessity, online learning will always be carried out if the Covid 19 pandemic has not ended. As educators, they also have the same obligation in managing the class with an online learning system, always adapting to the existing dynamic developments. It is hoped that the findings of various obstacles in this study will be valuable input for educators in conducting online learning.

\section{References}

[1] Winahyu, R. \& Djono, D. The Media Literacy in the 21st Century: The Role of Teacher in Historical Learning. International Journal of Multicultural and Multireligious Understanding. 2018. 5(4), 363.

[2] Churiyah, M., Sholikhan, S., Filianti, F., \& Sakdiyyah, D. A. Indonesia Education Readiness Conducting Distance Learning in Covid-19 Pandemic Situation. International Journal of Multicultural and Multireligious Understanding. 2020. 7(6), 491.

[3] Yandwiputra, A. R. Kuliah Jarak Jauh karena Virus Corona. UI: Bukan Lockdown. 2020. https://metro.tempo.co/read/1319537/kuliah-jarak-jauh-karena-virus-corona-ui-bukanlockdown/full\&view=ok

[4] Indonesia, C. 65 Kampus Kuliah dari Rumah, Sultan Yogya Ragukan Efektivitas. 2020. https://www.cnnindonesia.com/nasional/20200316110707-20-483756/65-kampus-kuliah-darirumah-sultan-yogya-ragukan-efektivitas.

[5] Pragholapati, A. Covid-19 Impact on Students. 2020. 1-6.

[6] Surani, D. \& Hamidah, H. Students Perceptions in Online Class Learning During the Covid-19 Pandemic. International Journal on Advanced Science, Education, and Religion. 2020. 3(3), 83-95.

[7] Milman, N. B. Distance Education. In International Encyclopedia of the Social \& Behavioral Sciences: Second Edition. In James D. Wright (Ed.), International Encyclopedia of the Social \& Behavioral Sciences (Second Edition). Elsevier. 2015.

[8] Murphy, M. P. A. COVID-19 and emergency eLearning: Consequences of the securitization of higher education for post-pandemic pedagogy. Contemporary Security Policy. 2020. 41(3), 492-505.

[9] Moore, J. L., Dickson-Deane, C., \& Galyen, K. E-Learning, online learning, and distance learning environments: Are they the same? Internet and Higher Education. 2011.14 (2), 129-135.

[10] Huang, R. The Chinese Experience in Maintaining Undisrupted Learning in COVID-19 Outbreak. Handbook on Facilitating Flexible Learning During Educational Disruption. 2020. 46.

[11] Zhang, D., Zhao, J. L., Zhou, L., \& Nunamaker, J. F. Can e-learning replace classroom learning? Communications of the ACM. 2004. 47(5), 75-79.

[12] Korucu, A. T., \& Alkan, A. Differences between m-learning (mobile learning) and e-learning, basic terminology and usage of m-learning in education. Procedia - Social and Behavioral Sciences. 2011. 15, 1925-1930.

[13] Nadeak, B. The effectiveness of distance learning using social media during the pandemic period of covid-19: A case in universitas kristen indonesia. International Journal of Advanced Science and Technology. 2020. 29(7), 1764-1772.

[14] Enriquez, M. A. S. Students' Perceptions on the Effectiveness of the Use of Edmodo as a Supplementary Tool for Learning. DLSU Research Congress. 2014. 6-11.

[15] Iftakhar, S. Google Classroom: What Works and How? Journal of Education and Social Sciences. 2016. 3, 1-17. 
[16] So, S. Mobile instant messaging support for teaching and learning in higher education. Internet and Higher Education. 2016. 31, 32-42.

[17] Kumar, V., \& Nanda, P. Social media in higher education: A framework for continuous engagement. International Journal of Information and Communication Technology Education (IJICTE). 2019. 15(1), 97-108.

[18] Engeness, I., Nohr, M., Singh, A. B., \& Mørch, A. Use of videos in the Information and Communication Technology Massive Open Online Course: Insights for learning and development of transformative digital agency with pre- and in-service teachers in Norway. Policy Futures in Education. 2020. 18(4), 497-516.

[19] Mazidah, Erna, M., \& Anwar, L. Developing an Interactive Chemistry E-Module for Salt Hydrolysis Material to Face the Covid-19 Pandemic. Journal of Physics: Conference Series. 2020. 1655(1).

[20] Fischer, E., \& Reuber, A. R. Social interaction via new social media: (How) can interactions on Twitter affect effectual thinking and behavior? Journal of Business Venturing. 2011. 26(1), 1-18.

[21] Suroto, Rizal, Y., Rahmawati, \& Hestiningtyas, W. Kebutuhan Media Pembelajaran Mahasiswa: Analisis Pada Mahasiswa Pendidikan Ekonomi. Economic Education and Entrepreneurship Journal. 2019. 2(2).

[22] Trianto, M. Mendesain model pembelajaran inovatif-progresif. Kencana. 2009.

[23] Sadiman, A. S. Media Pendidikan. PT Raja Grafindo Persada. 2010.

[24] Virginia, A. pada Era Media Baru: Studi Kasus Penggunaan Facebook oleh Digital Natives. Jurnal Komunikasi Indonesia. 2012. I, 77-85.

[25] Prensky, M. Digital Natives, Digital Immigrants. Horizon NCB University Press. 2001. Vol. 9, Issue 5.

[26] Palfrey, J., \& Gasser, U. Opening Universities in a Digital Era. The New England Journal of Higher Education. 2008. 23(1), 22-24. 